\title{
COSMOPOLITANISM AND PLANETARY STUDIES: \\ PARADIGMS FOR REWRITING THE PAST
}

\begin{abstract}
This paper discusses recent models of world literature rewriting in light of the 2018 Romanian Literature as World Literature, which remaps some of the most representative Romanian authors and movements according to the intersectional frameworks advanced by Immanuel Wallerstein's world systemstheory, Pascale Casanova's world republic of letters, and others. In their plea for what the book's editors call planetary, cosmopolitan studies, the sixteen contributors reread canonical Romanian texts and advocate for a new literary world order, within which Romanian literature is regarded in a less hierarchical/dichotomic fashion, as a literature of the world. This initiative seeks to reposition Romanian literature as a diverse, active, and dynamic partner in the world's cultural dialogue. My essay addresses a paradox which is very much at the centre of the book: how can one promote intercultural, non-hegemonic models of dialogue when translation and marketability still restrict the participation of "marginal" cultures in the planetary, cosmopolitan exchange of ideas?
\end{abstract}

Keywords: literary history; Romanian literature; planetary studies; world literature.

,[...] cosmopolitanism in a stricter sense includes a stance toward the coexistence of cultures in the individual experience. It is an intellectual and aesthetic stance of openness

toward divergent cultural experiences." 11 (Hannerz 239)

Since the end of the Cold War in the 1990s when the dualistic worldview was replaced by multipolar globalisation, the speed by which "the past" has been reread, rewritten, and rebranded according to paradigms ranging from postcommunism, postcolonialism, globalism, multiculturalism, and more recently,

\footnotetext{
${ }^{*}$ University of North Carolina; USA.

${ }^{11}$ Cited in Haun Saussy, Introducing Comparative Literature-New Trends, "The Return to Literature," 141.
} 
cosmopolitanism, and planetary studies has increased constantly. The anxieties of comparison $^{12}$, which prompted such cultural rereadings and rewritings in an effort to remap regions, cultures, canons, and to reassign the "insider" and "the outsider" labels within the Republic of Letters ${ }^{13}$, have also, paradoxically, increased over time leading to a seemingly never-ending process of reimagining the past.

As early as 1995 Emily Apter noted that both postcolonialism and Continental comparatism, "having agreed on the subject's cultural selfmisrecognition," shared a propensity to "produce the subject as complexified; pulled back from the stereotype or the positive image; deferred and postponed in transnational, translational, transsexual, and trans-technological space" („Comparative Exile” 90). Since 1995, this complexified subject inhabiting a world of increasingly interwoven cultures has been engaged in an arduous process of remapping and amending the past, in an effort to unveil and possibly curtail the archaeology of power which sustains oppressive hierarchies and canons.

By 2015 Ursula Heise, who coordinated the most recent Report of ACLA, Futures, observed that the field of comparative studies could best be described by an emerging topography defined both by "conflicts over how to negotiate the global, regional, national, and local scales of literary production and reception and by comparative studies' engagement with old and new media; by its position in a matrix of new interdisciplinary research areas, many of which involve science or technology" (Futures 2). At the intersection of all these, within the United States, at least, such approaches specific to Comparative studies are coterminous with those at work in ethnic American Studies Departments, in Women, and in LGBT Programs where methodologies are "seeking new convergences between disciplines in the humanities, social and natural sciences"14. (Heise 5) All these, at least in project, attempt to come together in order to foster discourses defined as "interdisciplinary nurture."

\footnotetext{
12 The "anxieties of comparison" concept was used by Charles Bernheimer in the "Introduction" (pages 1-17) of the 1993 Report on the state of the discipline of Comparative Literature, which he coordinated. The Report was published Comparative Literature in the Age of Multiculturalism. Johns Hopkins University Press, 1995 which Bernheimer edited.

${ }_{13}$ The term has been famously launched by Pascale Casanova's homonymous book, The World Republic of Letters (2004).

${ }^{14}$ About the methodology underscoring the 2014-15 website of the decennial Report, Ursula Heise noted that by 2015 ideas about "what the report should deliver had metamorphosed from a set of diagnoses, standards, and prescriptions to a lively and at times controversial dialogue among a variety of researchers" (1).
} 
For all this intersectionality, however, scholars like David Damrosch claim that "world literature is almost always experienced by readers within the national context in which they live, and more particularly within the national markets in which books are published, reviewed, and assigned in classes," thus leading to a never-ending, shifting dynamic between the local and the global, the national, and the world. ("World Literature as Figure" 137)

Moreover, despite all attempts at subverting imperialist, colonial-era hierarchies, the prevailing practice is, according to Theo D'haen, still one which regards "world literature" as NATO literature: the literatures in question being French, English, German, Spanish, and Italian." This is the case because so far "discussion on world literature was almost exclusively restricted to German, French, and U.S. comparative literature circles." Ironically, even such version of NATO world lit "was already an overstatement as usually only about one fourth of the literatures in the fifteen NATO languages receive[d] any actual sustained attention." 15 (D'haen 3)

Such critiques of the now pervasive English-language model of world literature are not new. So far its results are that works are mostly read in translation, thus literary analysis lean heavily on the this market, and on the profit-driven book distribution networks rather than reflecting each culture's book topography. In fact, misgivings about these phenomena have been voiced repeatedly in the United States, during the past six decades, at least since the 1965 Levin ACLA Report.

In response to such long term grievances, two recent, ambitious cultural histories situated at the cross-roads of American, Romanian, and East Central European Studies chose to address the challenge of cultural relationality in an ever-fluid world system with constantly adjusting epistemologies. The four volume History of Literary Cultures of East -Central Europe ${ }^{16}$ (2004-2010) and Romanian Literature as World Literature ${ }^{17}$ (2018) revisit the past by remapping it according to non-organicist concepts which avoid linking one culture to a specific location, language, history, thus, ultimately to any specific nation. Their metacritical discourses question nationalism and shed light onto ignored networks of exchanges through which marginal(ized) cultures have long been in

\footnotetext{
${ }^{15}$ Theo D'haen, The Routledge Concise History of World Literature, 2011.

${ }^{16}$ Marcel Cornis-Pope and John Neubauer, eds. History of the Literary Cultures of East-Central Europe: Junctures and Disjunctures in the $19^{\text {th }}$ and $20^{\text {th }}$ centuries (2004- 2010).

${ }_{17}$ Mircea Martin, Christian Moraru, Andrei Terian, eds. Romanian literature as World literature, 2018.
} 
dialog with the world. As part of the effort to redefine our view of the world and to build consensus among cultures by remapping the past, both histories are significant contributions to cosmopolitan and planetary studies and provide valuable epistemologies of rereading and rewriting cultural histories.

Significantly, these histories of literature and culture were incorporated in the long term projects of two important American professional organizations: the International Comparative Literature Association (ICLA) and the American Council for Learned Societies (ACLS). The four-volume History of Literary Cultures of East-Central Europe 18 (2004-2010) was part of a series of new literary histories supported by the ICLA which debuted with New Literary History of America, edited by Greil Marcus and Werner Sollors (2009), while Romanian Literature as World Literature is part of Bloomsbury's series of (national) literatures revisited as world literatures.

Apart from putting exceptional scholarship in dialogue, what qualifies both approaches as contributions to the twenty first century literary and cultural history is their prospective quality; the fact that apart from being descriptive and analytical, they both are manifestos for innovative modes of relationality. In this respect they are also complementary works, emphasizing the transformative contribution of cross-cultural exchange networks which for centuries have placed cultures across the world in contact. As Marcel Cornis-Pope points out in his interview in Futures, the 2014-2015 Report of the State of Comparative Literature:

In addition to offering transnational studies of literary regions that stretch across continents, projects like ICLA-sponsored New Literary History of America, [...] and the four-volume History of the Literary Cultures of EastCentral Europe have challenged traditional literary histories based on national and even text-oriented premises, focusing also on other media, such as theater, opera, and occasionally visual art. Moving beyond the boundaries of national literatures, historical trends, and generic divisions, these histories seek those "junctures" that bring together various traditions, allowing for a cross-cultural interpretation. For example, East-Central Europe is organized around five kinds of "nodes" - temporal, generic, topographic, institutional, and figural - at which various literatures, genres,

\footnotetext{
${ }^{18}$ Marcel Cornis-Pope and John Neubauer, eds. History of the Literary Cultures of East-Central Europe: Junctures and Disjunctures in the $19^{\text {th }}$ and $20^{\text {th }}$ centuries (2004-2010).
} 
and historical moments come together, transcending national definitions. ("Comparative Literary History" 36)

\section{The History of the Literary Cultures of East-Central Europe and Romanian} Literature as World Literature are the result of such vast projects of rereading and rewriting the shifting dynamic of cultural networks. Remarkably, the two cosmopolitan histories of culture meet in their goal of bringing forward instances of cross-cultural cooperation instead of focusing on national/nationalistic agendas and divisions or on globalizing ideologies and culturally imperialist practices.

In drawing the new topographies, the History of East Central European Cultures edited by Marcel Cornis- Pope and John Neubauer, engages with Mario J. Valdés and Linda Hutcheon's ${ }^{19}$ theories of hybrid comparative literary history, whether cultural or identity-related, with discussions of the local and the regional versus the national and the global, and last but not least with theories of intermediality, which emphasize the complex interplay of form, medium, and technology in recent cultural productions.

Romanian Literature as World Literature, (RLWL) edited by Mircea Martin, Christian Moraru, and Andrei Terian uses similar premises with the goal "of intervening in a major, ongoing conversation in $21^{\text {st }}$ century criticism and theory" 20 about new ways of mapping world cultures. Using Immanuel Wallerstein's world-systems theory ${ }^{21}$ and Pascale Casanova's world republic of letters

\footnotetext{
${ }^{19}$ See "Rethinking Literary History Comparatively"

20 "Our response and the book itself eventually had to do with a certain way of intervening in a

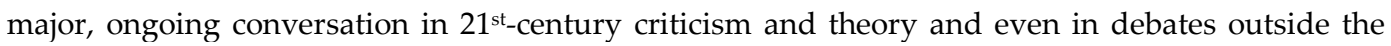
study of literature in hopes, among other things, of drawing scholars who may be interested, if not in Romanian literature per se, then at least in the broader, critical-theoretical issues with which we engage head-on across Romanian Literature as World Literature." https://bloomsburyliterarystudiesblog.com/continuum-literary-studie/2018/05/revisiting-nationalliteratures-in-the-21st-century.html

${ }^{21}$ Wallerstein's world systems theory postulates that "the world is one interconnected collection of nations and states that, due to the initial wave of European colonialism in the late fifteenth and sixteenth centuries, is dominated by economic centers in Europe and North America." The worldsystem thus configured according to the inter-regional and transnational division of labor, is divided into "core countries, semi-periphery countries, and the periphery countries. Core countries focus on higher skill, capital-intensive production, and the rest of the world focuses on low-skill, labor-intensive production and extraction of raw materials. This constantly reinforces the dominance of the core countries."
} 
as theoretical models, the editors seek to extract Romanian literature from a merely national and nationalistic context and place it into a planetary one, with the explicit goal of highlighting the Romanian participation in cosmopolitan cultural exchanges over time.

The 'worlding' of our literary disciplines and individual endeavours, their coming together in the world arena," note Moraru and Terian "is one of the most consequential processes marking the latest two decades ${ }^{22}$ " a process that is "empowering both epistemologically and politically." In RLWL such a metacritical historic model "has allowed not only for new readings of whole national traditions and individual authors' bodies of work but also for the repositioning of these-or some of these-patrimonies on the world map of literary values in a less hierarchical, more non-hegemonic fashion. A new literary world order seems now possible, beyond utopias [...]. (Introduction 21)

Within this new axiological makeup of the global literary scene, Romanian literature, typically relegated to the status of "minor," "peripheral," "mimetic" culture can be granted a substantial presence. The condition, though, notes Moraru, "is just that you have to make a strong case for it. Making this very case is the overall objective of our book. In this sense, Romanian Literature as World Literature is a collective, critical-theoretical and political manifesto by 16 authors." 23

As a critical manifesto, $R L W L$ addresses issues of "critical mis-reading and (self-)mis-representation that have been perpetuated internally by the nationalist paradigm dominating Romanian literary history for the past two centuries. On the world market, mis-readings of Romanian literature were caused by the ideological impositions from beyond the Iron Curtain, the lack of good translations, and the biased mechanisms of promotion coupled with cultural colonialism." ${ }^{24}$ Under these circumstances, the editors and contributors to RLWL

\footnotetext{
${ }^{22}$ This was documented in the 2017 Heise Report.

${ }^{23}$ Moraru is no stranger to writing theoretical manifestos, if only one thinks back to the 1980s when Generatia 80 (The 80s Generation) was launched, and especially to the years when Moraru was at the helm of this generation's journal, Contrapunct, in the early years after the fall of communism.

${ }^{24}$ This presentation of the anthology is part of the review I published in the Canadian Review of Comparative Literature / Revue Canadienne de Littérature Comparée, Volume 45, Issue 4, Décembre
} 
choose to reposition Romanian literature on the world scene, claiming that "when reframed intersectionally, as nodal sub-systems of a vaster, ever fluid continuum, the so-called 'marginal,' 'minor,' and 'small' literatures acquire an unforeseen and unorthodox centrality" (Introduction 5). The first step they take, is to welcome connections beyond spatial borderlines, and to destabilize the "one language-one nation-one literature organic correspondence" (Introduction 9). Since the prevalent nationalist paradigm of literary history and criticism throughout modernity is responsible for making categories such as locality and specificity (of the "national spirit") central to literary history-writing, now it's the time to revise the paradigm and bring neglected world-wide networks of cultural interaction to the fore to explore their intersectionality.

In sync with network and system theories, postcolonial studies, and comparative literature, RLWL proposes novel ways of viewing the world literary canon, of rearranging the world cultural map, and advances the kind of literary criticism that is "world-oriented," "nodal," and based on a "liquid epistemology" - a type of interpretation that takes us beyond "nationally territorialized realit[ies]" (Introduction 16). Other critical models that resurface in various chapters are: Wai Chee Dimock, David Damrosch, Pascale Casanova, Emily Apter, Arjun Appadurai, Homi Bhabha, Anthony Appiah, John Neubauer, Marcel Cornis-Pope, Gayatri Spivak, Mario Valdez, Linda Hutcheon, Katherine Verdery, Larry Wolff, and Romanian names like Eugen Lovinescu.

Placing deterritorialization of literary history at the forefront, the contributors propose to "weaken the 'umbilical cord' between determinate locations and cultural formations such as discourse, identity, and community" (Introduction 7) which have been traditionally considered as organically linked to certain national territories. In decupling the spaces of "nation" and "literature" the book challenges the nation-building project of modernity (Goldis) rooted in the premise of the "indissoluble connection among language, literature, and nation" (Moraru 9).

More importantly, RLWL takes on the urgent task of questioning the "homogeneous," "ethnocentric," "racialist" and even "racist" perspective on Romanian literary history (Introduction 11) promoted by G. Calinescu's magnum opus, Istoria literaturii române de la origini până în prezent ${ }^{25}$ (1941). This

2018: 686-9.

${ }^{25}$ History of Romanian Literature from Its Origins to the Present (my translation). 
national synthesis has dominated the landscape of Romanian literary historiography since its publication, and over time, implicitly, though no less authoritatively, imposed the critical style that the contributors and editors of this book challenge and seek to replace. As Andrei Terian maintains, in its approaches RLWL breaks the "epistemological mould of methodological nationalism" and proposes instead "supra-, extra-, and transnational sites of expression, commerce and interchange" (13). The result is, in the wake of Dimock and Spivak, a reading that "unpack[s] a text's wordliness [...] as a bundle of relations with other texts, people, and places" (18) beyond those circumscribed by the nation-state. Consequently, Alex Goldis argues, such an interactional approach, which reconsiders the relationships between translations and transcultural intertextuality, on the one hand, and creativity/originality on the other, is able to reposition Romanian literature in the world arena as a system of flows and interactions.

In "After Imitation: Aesthetic Intersections, Geocultural Networks, and the rise of Modern Romanian Literature," Carmen Musat considers the history of the task of "the worlding" of Romanian authors and artistic movements by pointing out that at the beginning of the twentieth century, Eugen Lovinescu, the Romanian proponent of cultural synchronization, followed similar principles of cross-cultural dialog when maintaining that cultural imitation has been and should be a necessary step in creating original art works. Though many misunderstood Lovinescu's enthusiasm for imitation, Musat reminds us that imitation and creativity have never been one-directional flows between core and periphery.

Looking at writers like Paul Celan, Emil Cioran, Benjamin Fondane, and Tristan Tzara who notoriously belong to more than one idiom, literary tradition, and geo-cultural system, Musat asks us to reconsider the relationships "between a writer and his or her communities, between national literature and literatures by ethnic minorities, as well as between national and world literature" (116). Rereading canonical writers such as Ion Luca Caragiale, Tristan Tzara, Eugen Ionesco, and Emil Cioran from such a perspective, as many contributors of the book do, considering transatlantic connections established by Matei Calinescu, Mihai Spariosu, Marcel Cornis-Pope, and Virgil Nemoianu, all American critics of Romanian origin, or by the 1980s generation of writers' symbolic dialogue with the American Beat poets, is a way to bring into focus the original strategies by which individual Romanian writers harnessed the energy of cultural mimesis. 
In the same vein, contributors Caius Dobescu, Mircea Diaconu, Imre József Balazs, Paul Cernat, Doris Mironescu, and Bogdan Cretu reinforce the book's thesis by unveiling "how the worldness of Romanian literature has emerged at particular junctures in its history" (128) when it contributed creatively and uniquely to international movements such as the avant-garde, modernism, and post-modernism, and in so doing "plug[ged] itself into the world networks" (Introduction 21). In the wake of Gayatri Spivak's and Franco Moretti's programmatic texts which postulate the entering of world literature into a "planetary era," the contributors join Christian Moraru in hailing the remapping of world literatures made possible by the planetary turn in criticism and by cosmodernism, which Moraru previously defined as a "rationale and vehicle for a new togetherness, for a solidarity across political, ethnic, racial, religious, and other boundaries" (Cosmodernism 5).

$R L W L$ enthusiastically joins such re-readings and rewritings by unveiling ways in which canonical Romanian writers such as Mihai Eminescu (Terian 35) and I.L. Caragiale can be "plugged" into the world networks. Politerritoriality of literature produced by authors from the Republic of Moldova, Bukovina, Banat (Diaconu), the reterritorialization of Romania's Hungarian literature (Balasz) are some possible ways of rereading the past of multi-ethnic, cosmopolitan regions and writers. Several contributors also point out that the Romanian avant-garde, and internationally-renowned authors such as Mircea Eliade, Emil Cioran, and Eugene Ionesco are already part of the world-network since they functioned de facto within the international context. With locally-known authors such as Dimitrie Cantemir, Nicolae Milescu (Cretu 55), Ion Budai Deleanu (Dobrescu 77), and even more so with regionally and ideologically-specific cultural phenomena such as Socialist Realism (Martin 235), the world reader needs to be provided context in order to understand such authors and phenomena within a worldly framework instead of that of local isomorphisms.

It is precisely in this respect that RLWL manages to establish a dialogue between the world and Romanian literature by "undertaking the effort not only to translate Romanian literature to the world, but to translate it for the world in a manner that is already of the world." Since the articles collected in this book were mostly written in Romanian by Romanian scholars, we can say that these texts themselves went through the process of "worlding" at the hands of the book's translator (Laura Walker) and of the editors. Such understated effort which underscores the production and distribution of $R L W L$ also testifies to the 
multinational and at the same time, transnational labor necessary to bring forth such projects.

Highlighting such spirit of trans-national collaboration, Caius Dobrescu's "Soft Commerce and the Thinning of Empires: Four Steps Toward Modernity" and Bogdan Stefanescu's "Romanian Modernity and the Rhetoric of Vacuity: Toward a Comparative Postcolonialism," challenge and complicate the traditionally linear model of comparatism, which worked with static and dichotomous concepts such as "centre-periphery" and "East-West," and thus gave rise to "self-consciousness" and a rhetoric of vacuity regarding Romanian modernity. By pointing out the often ignored existence of paraimperial, transmetropolitan (82-7) modes of cultural "soft commerce" in which modern Romanian literature played various empires' cultural pulls one against another, Dobrescu's study upends the traditional mimetic paradigm which regards Romanian authors always in terms of their debt to various cultural influences, and instead insists on the creative mechanisms by which Ion Budai Deleanu, Gheorhe Sincai, Dimitrie Cantemir, Ion luca Caragiale, and others both used and challenged the mimetic paradigm and along with it, the condition of cultural periphery.

In comparing the reaction to the cultural trauma provoked by "malignant modernity" in the Second (now ex-communist) World and the Third (formerly colonized) World cultures, Bogdan Stefanescu proposes an alternative model of identity formation: instead of "the void" as a trope for the belated, mimetic modernization and modernity of non-Western cultures, he opts for a transhistorical, nodal approach that focuses on "discursive similarities of world cultures which, though worlds apart, share generic, structural, and relational similarities" (265). It is through such readings that traumatized subjectivities like those emerging from the Holocaust and colonial traumas, which, historicallyspeaking, had no points of contiguity in space, may come together "by virtue of their shared and generic features" (Stefanescu 265) and thereby advance their own perspective about the traumas they experienced.

In "Socialist Realism, a Geoliterary Ecumene of the East," Mircea Martin puts the book's geo-mapping model to work in a minute, cross-cultural analysis that fleshes out specificities which singled out Socialist Realism as a vector of Sovietization in Eastern Europe. By comparatively examining how the former affected Czech, Polish, and Romanian literature, Martin makes the case that the rift with modernity that Socialist Realist poetics/ideology engendered throughout 
Eastern Europe is responsible for the difference in priorities that separates the communist and the Western worldviews beginning in the 1960s, even as the Socialist Realist experiment was abandoned. In response to many American scholars' wonder at Eastern European authors' lack of appetite for postcolonial modes of rereading, Martin notes, "Understandably, retrieving national tradition and resuming modernist experimentation [in an effort to reconnect culturally with the rest of Europe and with the Western world from which it was severed by the communist Iron Curtain] struck Romanian writers and critics as more urgent than critiquing modernism and moving into the postmodern" (253). Or into the postcolonial age, I would add, if that means critiquing The French and the British (empires) but not the Soviet Union.

By the same token, insists Martin, such locally specific circumstances explain why Romanian intellectuals "felt solidarity with a nation-state whose sovereignty continued to be threatened by the U.S.S.R." (253) and why after the end of the Cold War they proved again out-of-sync with the multicultural and postcolonial agendas of American comparatism. Locally specific historical circumstances which Martin invokes also illuminate why Eastern Europe was again late in joining the counterculture of the 1960s and 1970s and seemed to exhibit symptoms of yet another phase of its proverbial "belatedness." As a remedy to such misreadings, Martin suggests a renewed and better informed dialogue between Eastern European and Western critical models, in the spirit of really inhabiting the same Republic of Letters.

True to the spirit of cosmopolitanism, the reading model advanced by RLWL considers writers from the multicultural and multilingual Romanian spaces such as those of Bukovina, Banat, and Transylvania. Authors such as Nobel-winning Herta Muller, Peter Demeny, Peter Motzan, Adam Puslojic, discussed by Mircea Diaconu and Zsolt Lang, Imre Bodor discussed by Imre József Balazs, join those "deracinated"/uprooted names to which Ovidiu Morar refers when talking about the role of Romanian Jews in the international avantgarde, or those of famous Romanian exiles either from the inter-war period and post-1960s, such as Andrei Codrescu, and Norman Manea, whom Mihai Iovanel, Paul Cernat, and Doris Mironescu consider.

Teodora Dumitru makes the case that Romanian postmodernism which developed in dialogue with the American Beat poets during the 80s in Romania is yet another node attesting the fluid, intertextual interaction of ideas that has often defied ideological impositions and spatial borders. However, in order for 
such nodes to persist, Romanian literature needs to exist within a constant flux of translations from other world texts and for the world market. This is Mihaela Ursa's thesis captured in her title "Do You Speak Translatese?" and further in her essay which provides figures of texts translated and discusses strategies of international promotion only to point out that the ideal Republic of Letters advanced by RLWL might be in jeopardy if the Romanian state is not subsidizing translations and the international, commercially-driven market is allowed to dictate how much and what is being translated.

Ursa's article, placed last in the book, strengthens its argument about the multiple dimensions of cultural translation and the need to constantly feed its flows and expand the networks between various literary hubs of the planet. These being noted, one may not ignore the paradox that while for the contributors and editors of $R L W L$, the book signals that Romanian literature is also part of the "world club," the Bloomsbury series of "Literatures as World Literatures" which has already published collections about Dutch and Flemish, Brazilian, African, Danish, and American literatures, has also promoted a monolingual approach, privileging English as a lingua franca of world comparatism.

If the time has come for what the Bloomsbury series calls "a novel approach to world literature" which analyses "specific constellations-according to language, nation, form, or theme-of literary texts and authors in their own world-literary dimensions," how is the series addressing the aporias of translation which continue to privilege English as a lingua franca and the few NATO literary traditions already benefitting from solid corpuses of translations? How is such a series positioning itself to the fact that, as we speak, in the American academia there is only a small number of language academic programs preparing new generations of translators and exegetes ${ }^{26}$ in what has been traditionally called "marginal" or "minor" (Eastern/East-Central European) literatures?

\footnotetext{
${ }^{26}$ One may need to consider that Romanian Programs on the North American continent are rather sparse (only two supported by Romanian Language Institute in the United States-at Columbia University and Arizona State University) and one in Canada (York University). More often than not the existing Programs, like the one at Indiana University Bloomington, at University of Seattle, at Ohio State, or the one I am teaching in at UNC Chapel Hill are supported by the efforts of devoted Romanian scholars/professors from various Humanities Departments or by grants that list Romanian as a "less taught" language similar to Catalan and Basque, yet of interest for the US Government.
} 
University of Bucharest Review $\approx$ Vol. XI/2021, no. 1 (new series)

Re-writing, Re-imagining the Past (III)

With intentional capital investments in translation and language programs moving at their own pace, it may take a couple of decades until remappings of past canons and rewritings such as those proposed by RLWL and History of East Central European Cultures can enter a more substantive and generalized worlddialogue. Meanwhile, based on the recent tendencies of cultural markets, one may expect that visual and digital media would be the most likely locomotives for higher visibility of marginalized traditions, whose "minor" status might, for once be the very reason to bring them into renewed focus.

\section{Works Cited}

Apter, Emily. "Comparative Exile. Competing Margins in the History of Comparative Literature." Comparative Literature in the Age of Multiculturalism. Johns Hopkins University Press, 1995: 86-97.

Apter, Emily. Against World literature: On the Politics of Untranslatability. London, Verso, 2013.

Bernheimer, Charles, editor. Comparative Literature in the Age of Multiculturalism. Johns Hopkins University Press, 1995.

Casanova, Pascale. The World Republic of Letters. Translated by M.B. DeBevoise. Cambridge, MA: Harvard University Press, 2004.

Călinescu, G. Istoria literaturii române de la origini până în prezent. $2^{\text {nd }}$, revised ed., prefaced and edited by Alexandru Piru, Bucharest: Minerva, 1982.

Cernat, Paul. "Communicating Vessels: The Avant-Garde, Antimodernity, and Radical Culture in Romania between the First and the Second World Wars," Romanian Literature as World Literature, Bloomsbury Publishing, 2018: 195-215.

Cornis-Pope, Marcel and John Neuebauer, eds. History of the Literary Cultures of East-Central Europe: Junctures and Disjunctures in the $19^{\text {th }}$ and $20^{\text {th }}$ centuries. John Benjamins Publishing Company (2004- 2010).

Domingues, César. “Comparative Literary History. A Conversation with Marcel Cornis-Pope and Margaret R. Higonnet." Futures, Abingdon, Oxon; New York, N.Y.: Routledge, 2017: 35-48.

Damrosch, David. "Translation and National Literature." In A Companion to Translation Studies, edited by Sandra Bermann and Catherine Porter, Chichester: John Wiley \&Sons, 2014: 347-60.

Damrosch, David. What is World literature? Princeton: Princeton University Press, 
2003.

Damrosch, David. "World literature as Figure and as Ground." Futures, 134 Abingdon, Oxon; New York, N.Y.: Routledge, 2017: 140.

D'haen, Theo. The Routledge Concise History of World Literature, Routledge, 2011.

Diaconu, Mircea, A. "Reading Microliterature: Language, Ethnicity, Polyterritoriality," Romanian Literature as World Literature, Bloomsbury Publishing, 2018: 135-157.

Dimock, Wai Chee and Lawrence Buell, editors. Shades of the Planet. American literature as World Literature. Princeton, NJ: Princeton University Press, 2007.

Dobrescu, Caius. "'Soft' Commerce and the Thinning of Empires: Four Steps Toward Modernity," Romanian Literature as World Literature, Bloomsbury Academic, 2018: 77-95.

Dominguez, Cesar, Haun Saussy, Dario Villanueva, editors. Introducing Comparative Literature: New Trends and Applications. Taylor \& Francis, 2014.

Goldiș, Alex. "Beyond Nation Building: Literary History as Transnational Geolocation," Romanian Literature as World Literature, Bloomsbury Publishing, 2018: 95-115.

Hutcheon, Linda, and Mario J. Valdes, editors. Rethinking Literary History: A Dialogue on Theory. Oxford: Oxford University Press, 2002.

Heise, K. Ursula, editor. Futures of Comparative Literature. ACLA State of the Discipline Report, Abingdon, Oxon; New York, N.Y.: Routledge, 2017.

Heise, K. Ursula. "Comparative Literature and the New Humanities." Futures, Abingdon, Oxon; New York, N.Y.: Routledge, 2017.

Imre József Balazs. "Trees, Waves, Whirlpools: Nation, Region, and Reterritorialization of Romania's Hungarian Literature," Romanian Literature as World Literature, Bloomsbury Publishing, 2018: 157-75.

Iovănel, Mihai. "Temporal Webs of World Literature: Rebranding Games and Global Relevance after the Second World War-Mircea Eliade, E.M. Cioran, Eugène Ionesco," Romanian Literature as World Literature, Bloomsbury Publishing, 2018: 217-35.

Lovinescu, Eugen. Istoria literaturii române contemporane, vols. 1-6. Bucharest, Ancora, 1926-1929.

Mignolo, Walter. Local Histories/Global Designs: Coloniality, subaltern Knowledge, and border Thinking. Princeton University Press, 2012.

Mironescu, Doris. "How Does Exile Make Space? Contemporary Romanian 
University of Bucharest Review $\propto$ Vol. XI/2021, no. 1 (new series)

Re-writing, Re-imagining the Past (III)

Émigré Literature and the Worldedness of Place: Herta Muller, Andrei Codrescu, Norman Manea," Romanian Literature as World Literature, Bloomsbury Publishing, 2018: 289-309.

Martin, Mircea. "A Geoliterary Ecumene of the East: Socialist Realism-the Romanian Case," Romanian Literature as World Literature, Bloomsbury Publishing, 2018: 235-255.

Martin, Mircea, Moraru Christian, and Terian, Andrei, eds. Romanian Literature as World Literature. New York, Bloomsbury Publishing, 2018.

Morar, Ovidiu. "Cosmopolis, Deracinated, étranjuifs: Romanian Jews in the International Avant-Garde." Romanian Literature as World Literature, Bloomsbury Publishing, 2018: 175-95.

Moraru, Christian. Cosmodernism. American Narrative, Late Globalization, and the New Cultural Imaginary. University of Michigan Press, 2011.

-----. '“'World,' 'Globe,' 'Planet'. Comparative literature, planetary studies, and Cultural Debt after the Global Turn." Futures, 2015.

Moraru, Christian and Andrei Terian. "Introduction." Romanian Literature as World Literature, Bloomsbury Publishing, 2018: 1-33.

Moretti, Franco. Graphs, Maps, Trees: Abstract Models for a Literary History. London: Verso, 2005.

Mușat, Carmen. “After 'Imitation': Aesthetic Intersections, Geocultural Networks, and the Rise of Modern Romanian Literature," Romanian Literature as World Literature, Bloomsbury Publishing, 2018: 115-33.

Saussy, Haun, "The Return to Literature." Introducing Comparative Literature: New Trends and Applications. Taylor \& Francis, 2014: 141-67.

Spivak, Chakravorty Gayatri. An Aesthetic Education in the Era of Globalization. Cambridge, Mass: Harvard University Press, 2012.

Ștefănescu, Bogdan. "Romanian Modernity and the Rhetoric of Vacuity: Toward a Comparative Postcolonialism." Romanian Literature as World Literature, Bloomsbury Publishing, 2018: 255-71.

Terian, Andrei. "Mihai Eminescu: From National Mythology to the World Pantheon," Romanian Literature as World Literature, Bloomsbury Academic, 2018: 35-55.

Ursa, Mihaela. "Made in Translation: A National Poetics for the Transnational World." Romanian Literature as World Literature, Bloomsbury Publishing, 2018: 309-325. 